\title{
BMR

\section{COLCHICINE, INFLAMMATION AND FIBROSIS IN CARDIOVASCULAR DISEASE: MERGING THREE CLASSICAL TALES}

\author{
George N. Chaldakov* and Peter I. Ghenev \\ Department of Anatomy and Cell Biology and Department of General and Clinical Pathology, Medical \\ University, Varna, Bulgaria
}

\section{ABSTRACT}

Colchicine, isolated from Colchicum autumnale, is a drug for acute gouty arthritis known from thousands of years whose use has survived to modernity. Over the past decades, the use for this very old drug extended beyond gout therapy. This was due to the advance in knowledge of (i) association of hyperuricemia and gout with cardiovascular disease, (ii) cytoskeletal microtubules (MT), and (iii) anti-inflammatory and antifibrotic effects of colchicine, a classical MT-disassembling agent (antitubulin). Here, we present the Bulgarian contribution to colchicine potential in the therapy of cardiovascular disease that has emerged in the early 1970 's in the Laboratory of Electron Microscopy, Medical Institute, Varna, Bulgaria, studying the secretory ( $f$ brogenic) function of vascular smooth muscle cells. From this time onward, low-dose colchicine (LoDoCo, 0.5 - $1.0 \mathrm{mg} /$ daily) was increasingly administered orally for therapy of cardiovascular disease such as acute coronary syndromes, cardiac surgery postoperative atrial fibrillation, pericarditis, cardiac hypertrophy-associated heart failure, and systemic necrotizing vasculitis. Thus colchicine might be a new tool in the present therapeutic armamentarium for these diseases. It is simply an example of MT-disassembling drugs. Further studies will definitely be required before gaining real confidence in this kind of antitubulin therapy. This may lead to developing new and more specific antitubulins for therapy of cardiovascular disease. Biomed Rev 2017; 28: 105-110.

Keywords: microtubules, tubulin, colchicine, antitubulins, cardiovascular diseases, inflammation, fibrosis

\section{INTRODUCTION}

The colorful saga of Colchicum autumnale (commonly known as autumn crocus) stretches back over 3000 years. Ancient writers have described it as the remedy for patients suffering debilitating pain due to acute gout arthritis. Today, this therapeutic effect of Colchicum autumnale, from which colchicine has been isolated more than 100 years ago, is known to be due to its anti-inflammatory action.

Over the past decades, advances in the knowledge of (i) cy- toskeletal microtubules (MT) и (ii) cellular effects of colchicine as MT-disassembling agent have led to potential new uses for this very old drug. For instance, colchicine has been used to treat familial Mediterranean fever (and related amyloidosis and recurrent pericarditis), Behçet's disease, acute febrile neutrophilic dermatosis (Sweet's syndrome), epidermolysis bullosa acquisita, aphthous stomatitis, also liver cirrhosis, scleroderma, idiopathic pulmonary fibrosis and other fibro-inflammatory diseases (1-4).

Received 24 November 2017, accepted 6 December 2017.

*Correspondence and reprint request: Dr George N. Chaldakov, Department of Anatomy and Cell Biology, Medical University, BG-9002 Varna, Bulgaria

E-mail: chaldakov@yahoo.com 


\section{$\because \because \bullet$ centrosome (MTOC)}

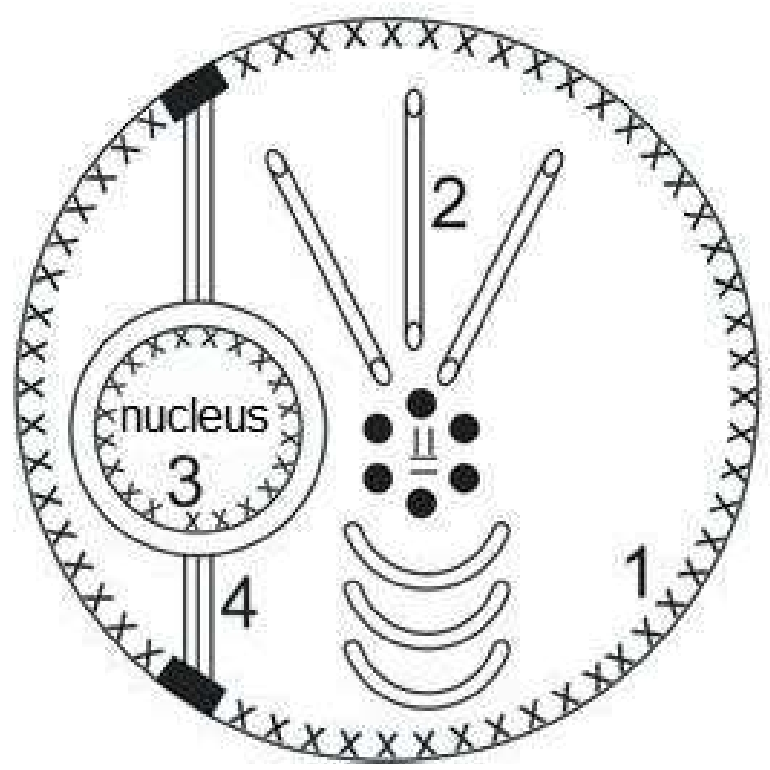

Figure 1. Schematic illustration of microtubule-organizing center (MTOC) composed of centrosome represented by two centrioles $(=)$ and pericentriolar dense material ( $\gamma$-tubulin ring complexes) (•) located in trans-Golgi zone. Subplasmalemmal cytoskeleton (1 $\boldsymbol{x x \boldsymbol { x }}$ ), microtubules (2) nuclear lamina (3 xxx), intermediate filaments (4). From (32).
Here, we present briefly the Bulgarian contribution to possible potential of MT-disassembling drugs (antitubulins), such as colchicine, in the therapy of cardiovascular disease, e.g. acute coronary syndromes, myocardial infarction, peripheral atherosclerosis, atrial fibrillation, pericarditis, and cardiac hypertrophy-associated heart failure.

\section{MICROTUBULES AND COLCHICINE}

Cytoplasmic and mitotic spindle microtubules (MT) are $25 \mathrm{~nm}$ in outer diameter cytoskeletal structures composed of self-assembling heterodimers of $\alpha$ - and $\beta$-tubulin in collaboration with MT-associated proteins (MAP 1-3 and tau protein) and GTP/GDP. Microtubules originate from MT-organizing center (Fig. 1).

Colchicine binds with high affinity to specific domain of $\beta$-tubulin, resulting in (i) inhibition of tubulin assembly into MT, (ii) disassembly of preformed MT, and/ or (iii) inhibition of membrane-bound tubulin sensitive cellular processes. We prefer the term tubulin-targeting agents (MT-disassembling agents, antitubulins) $(1,8,9)$ instead of MT-targeting agents (10). In brief, tubulin and MT have been emerging as promising targets for new anti-inflammatory $(2,11-14)$, antifibrotic (1, 3-9), and anticancer (10) drugs.

In effect, colchicine inhibits various MT-dependent cellular processes, for example: (i) in interphase cells -
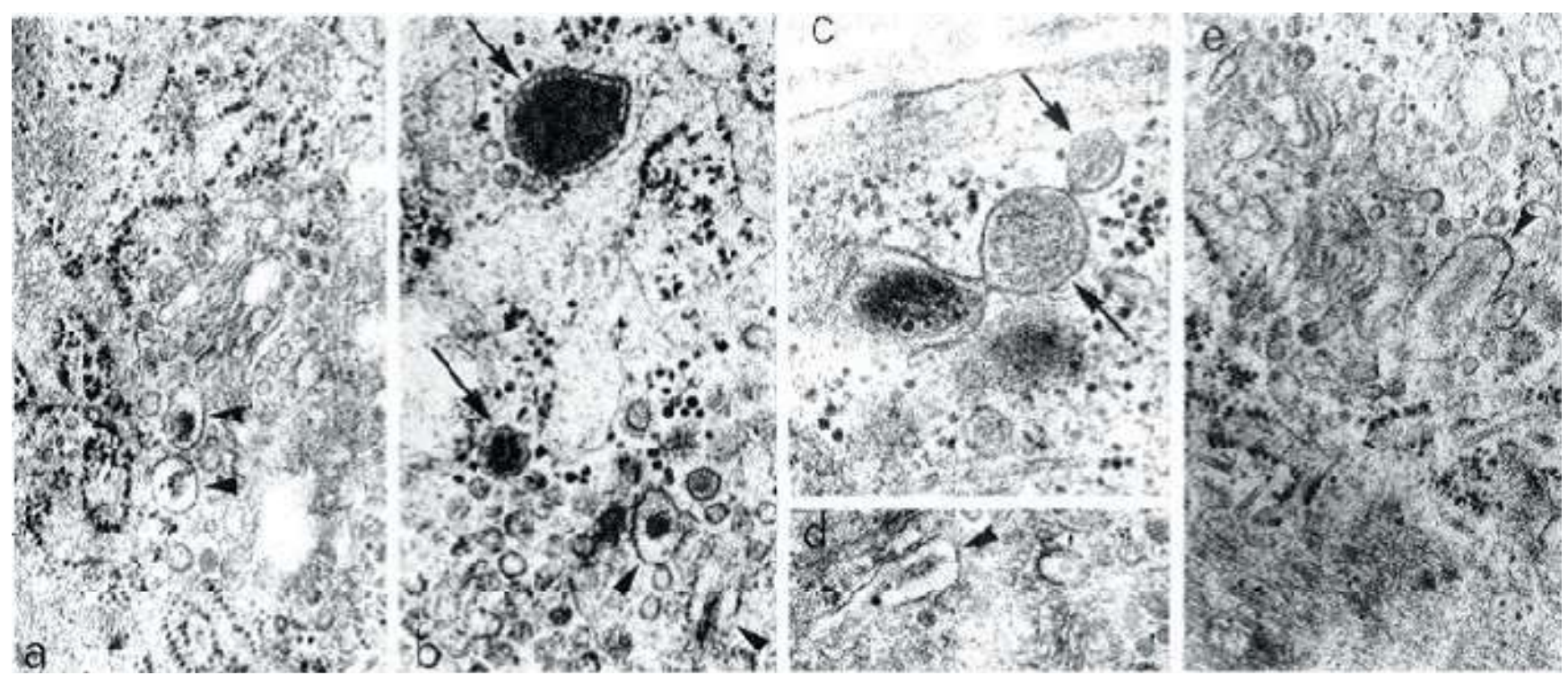

Figure 2. Electron micrographs of secretory-state (secretory phenotype) aortic smooth muscle cells of the rabbit. The cells possess less filaments and well-developed rough endoplasmic reticulum and Golgi complex-derived secretion granules (vacuoles), spherical-shaped (arrows) and elongated-shaped (arrowheads). a-e, x20 000. From (1, 9). 

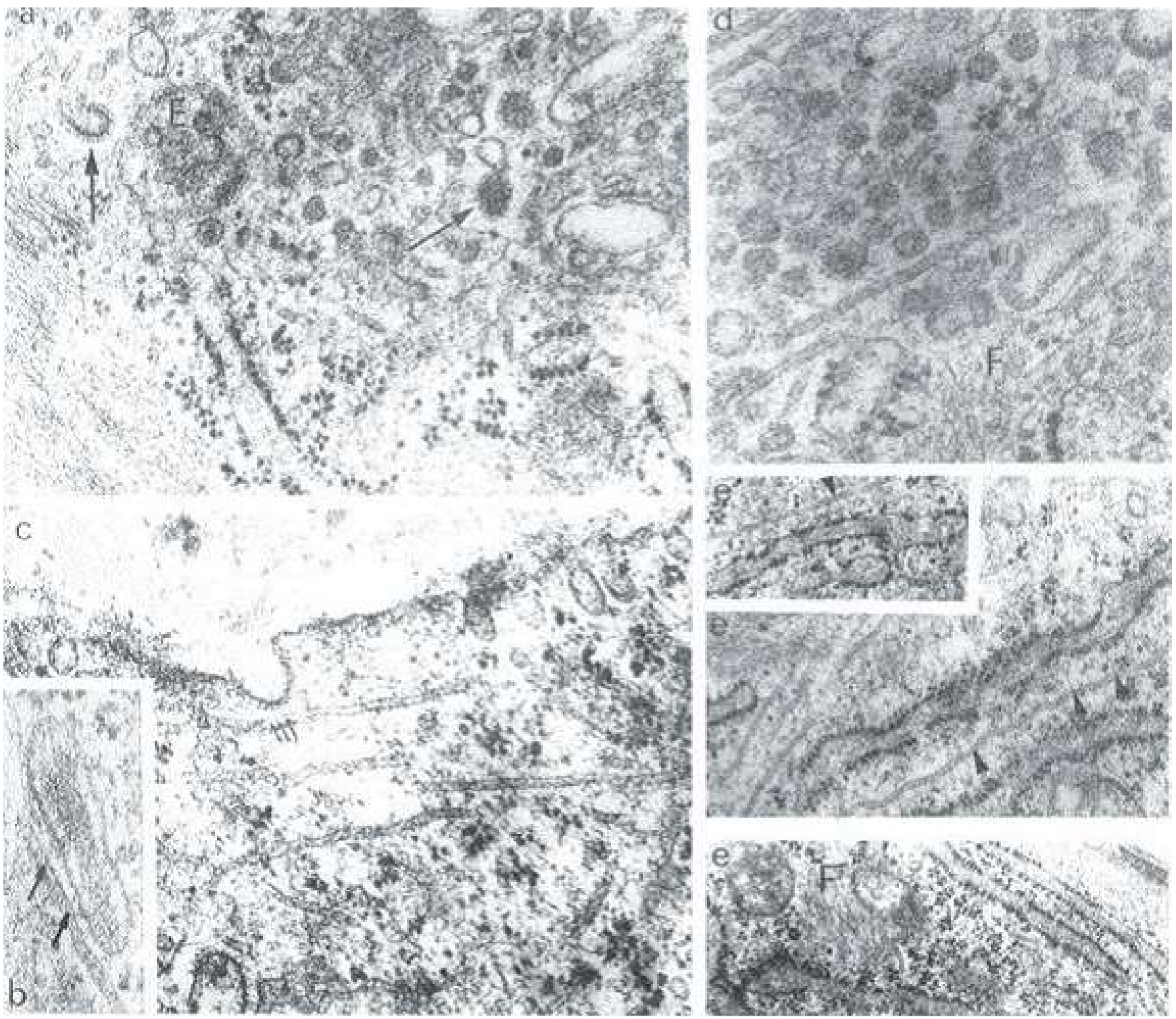

Figure 3. Electron micrographs of secretory-state (secretory phenotype) aortic smooth muscle cells of the rabbit. a. Golgiassociated clathrin-coated vesicles (arrows). b. Elongated vacuole linked via filamentous arms (two arrows) to microtubule. c. Plasmallema-derived coated pits (three arrows). d. Group of Golgi vesicles are sandwiched between microtubules. $\boldsymbol{e}$. Rough endoplasmic reticulum-associated microtubules (arrowheads) and filaments (F). a, c, d, x50 000; b, $80000 ; \boldsymbol{e}, 20000$. From (1, 9).

protein secretion including that of collagen and other matrix proteins realized by vascular smooth muscle cells (1, 5-9; Fig. 2-4), and (ii) in mitotically dividing cells - proliferation, the latter being out of the scope of present article. Colchicine also exerts anti-inflammatory action mediated via (i) inhibition of the secretion of proinflammatory cytokines and growth factors, and (ii) inhibition of NLRP3 inflammasome-mediated inflammation, nucleotide-binding oligomerization domainlike receptors, pyrin domain-containing 3 (NLRP3) inflammasome being a cytoplasmic protein complex, which senses pathogenic invasion through the activation of caspase-1 (cysteine-aspartic protease), which converts pro-interleukin (IL)-1ß and pro-IL-18 into IL-1ß and IL-18 respectively (2, 14a for colchicine and NLRP3 inflammasomes; 14b for Canakinumab - human monoclonal antibody neutralizing the action of IL-1ß, the production of which being significantly increased in cells with cholesterol crystal deposition, reminding of urate crystal deposition in gout, also other crystal deposition diseases (14c). Canakinumab Anti-inflammatory Thrombosis Outcomes Study (CANTOS) are recent clinical 

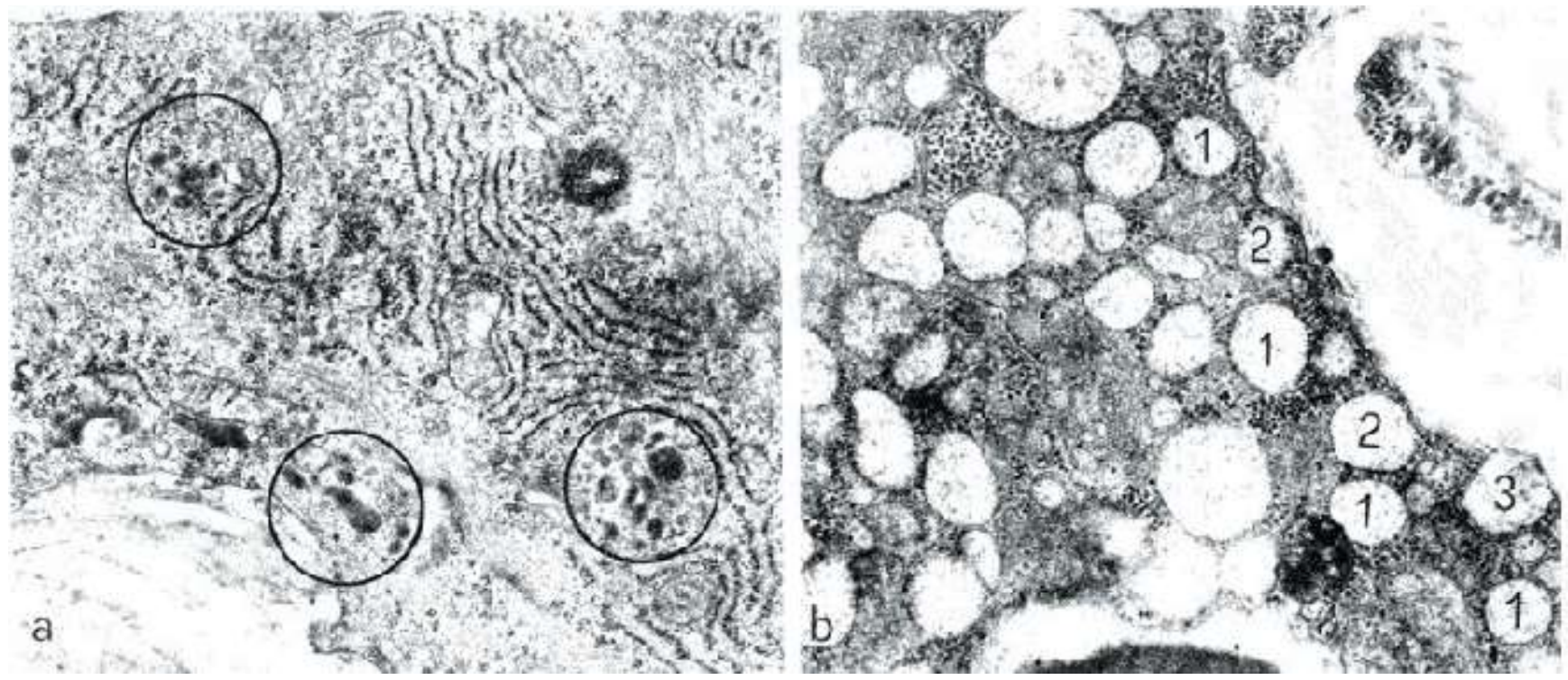

Figure 4. Electron micrographs of secretory-state (secretory phenotype) aortic smooth muscle cells of the rabbit treated with a sub-antimitotic dose of colchicine. The cells responded to the treatment by (a) an accumulation of secretion granules (circles), or (b) vacuolar type dilation of rough endoplasmic reticulum cisternae, some of them approaching the cell periphery $(1,2,3)$. $\boldsymbol{a}, \boldsymbol{b}, x 10000$. From $(1,9)$.

trials for patients with acute coronary syndromes.

\section{THE BULGARIAN CONTRIBUTION}

The concept of possible therapeutic potential of MTdisassembling drugs, such as colchicine, has emerged in the Laboratory of Electron Microscopy, Department of Anatomy and Histology, Medical Institute, Varna, Bulgaria, studying the secretory function of vascular smooth muscle cells (Fig. $2-4 ; 1,3,5-9$; also see 4,15 ). Preliminary proof for the possible antisecretory (antifibrotic) effect of colchicine was presented in a lecture delivered by one of the authors (GNC) at the International Symposium on Smooth Muscle of the Artery, held Heidelberg, Germany, October 1973, which was published in 1975 (5).

From this time onward, colchicine was increasingly administered for therapy of cardiovascular diseases (16-26). It has also been demonstrated that excess MT density is important for myocardial contractile dysfunction, suggesting that this may be one mechanism contributing to the development of heart failure due to cardiac hypertrophy $(27,28)$. Noteworthy, colchicine may restore the contractile activity of cardiomyocytes $(27,28$; also see 15,29$)$.

\section{CONCLUSION}

The use of low-dose colchicine (referred to as LoDoCo) might be a new tool, both anti-inflammatory and antifibrotic, in the present therapeutic armamentarium for cardiovascular disease. In 2010 FDA approved Colcrys (brand of colchicine) for use. However, a pharmaceutical company raised its price from as low as 10 cents per pill (generic colchicine) to $\$ 5$ per pill. $\$ 5$ versus 10 cents per pill of colchicine - a $5000 \%$ increase of its price, one more example of todays's global commercialization schemes.

Colchicine is simply an example of MT-disassembling drugs. Further experimental and clinical studies will definitely be required before gaining real confidence in this kind of antitubulin therapy. This may lead to developing new and more specific drugs with anti-inflammatory and antifibrotic effects in cardiovascular disease, targeting also (i) the MTbased motor proteins kinesin and dynein (see 32), (ii) posttranslational modification of tubulin, (iii) membrane-bound tubulin, (iv) non-tubulin-binding action of colchicine (requiring testing of lumicolchicine, an analogue of colchicine which does not bind tubulin, nor disrupt microtubules, also see 15), and (v) resolvins (pro-resolving lipid mediators) (reviewed in 33).

Considering the importance of atherosclerotic plaque's fibrous cap for the vulnerability of the plaque, we must proceed cautiously with antfibrotic action of colchicine $(30,31)$. 
Anyway we must recall Robert Frost's poem The Secret Sits:

We dance round in a ring and suppose,

But the Secret sits in the middle and knows.

\section{CONFLICT OF INTEREST STATEMENT}

The authors certify that they have no affiliations with or involvement in any organization with any financial interest in the subject matter discussed in the present Dance Round.

\section{ACKNOWLEDGEMENTS}

This Bulgarian contribution was made possible due to the staunch support and creative collaboration over the years of our brain-and-heart friends (BHF) Anna Kadar, Jörg Grünwald, Yukio Yamori, Toru Nabika, Takashi Fujiwara, Luigi Aloe, Marco Fiore, Plamen Panayotov, Antonia R. Kisheva, Anton B. Tonchev and Stanislav Yanev. The linguistical improvement of the manuscript made by Professor Denys Wheatley (University of Aberdeen, UK) is greatly appreciated. We apologize to the authors of many relevant articles that have not been quoted here for reasons of brevity.

\section{REFERENCES}

1. Chaldakov GN. George E. Palade lecture. Human body as a multicrine system, with special reference to cell protein secretion: From vascular smooth muscles to adipose tissue. Biomed Rev 2016; 27:VIII-XIX.

2. Martınez GJ, Robertson S, Barraclough J, Xia Q, Mallat Z, Bursill C, et al. Colchicine acutely suppresses local cardiac production of inflammatory cytokines in patients with an acute coronary syndrome. $J$ Am Heart Assoc 2015;4:e002128. DOI: 10.1161/ JAHA.115.002128.

3. Chaldakov GN, Deyl Z, Vankov VN. Colchicine: possible new application of its antifibrotic (antisecretory) action. Physiol Bohemoslov 1987;36:1-7.

4. Solak Y, Siriopol D, Yildiz A, Yilmaz MI, Ortiz A, Covic $\mathrm{A}$, et al. Colchicine in renal medicine: New virtues of an ancient friend. Blood Purif 2017;43:125-135. DOI: 10.1159/000454669.

5. Chaldakov GN, Nikolov SD. Ultrastructure of the arterial smooth muscle cell. In: Wolf S, Werthessen NT, editors. The Smooth Muscle of the Artery. New York City, NY: Plenum Press. Adv Exp Med Biol 1975; 57:14-20.

6. Chaldakov G, Nikolov S, Vankov V. Fine morphological aspects of the secretory process in arterial smooth muscle cells. Part 2. Role of microtubules. Acta Morph Acad Sci Hung 1977; 25:167-174.
7. Chaldakov GN, Kadar A. Microtubules in arterial smooth muscle cells in vivo and in tissue culture. An electron microscope study. In: W. Hauss, R. Wissler, R. Lehman, editors. State of Prevention and Therapy of Human Arteriosclerosis and in Animal Models. RheinischWestfalische Akad. Der Wissenschaften, 1978, p. 211-231.

8. Chaldakov GN. Antitubulins - a new therapeutic approach for atherosclerosis? Atherosclerosis 1982; 44: 385-390.

9. Chaldakov GN, Vankov VN. Morphological aspects of secretion in the arterial smooth muscle cell, with special reference to the Golgi complex and microtubular cytoskeleton. Atherosclerosis 1986;61:175-192. DOI: 10.1016/0021-9150(86)90137-1.

10. Lu Y, Chen J, Xiao M, Li W, Miller DD. An overview of tubulin inhibitors that interact with the colchicine binding site. Pharm Res 2012; 29:2943-2971. DOI: 10.1007/ s11095-012-0828-z.

11. Chaldakov GN. Anti-inflammatory drugs and ischemic heart disease: new considerations (a cell biologist's proposal to cardiologists). J Am Coll Cardiol 1991; 17:1445-1446.

12. Chaldakov GN. Proposal for clinical trials using anti-inflammatory drugs in the therapy of angina pectoris, myocardial infarction and coronary restenosis after angioplasty and bypass grafting. Med Hypotheses 1992; 37:74-75.

13. Chaldakov G. Colchicine in the therapy of cardiovascular disease. The Bulgraian contribution. Scr Sci Med 2017; 49(4): 84-86.

14. Yanev S, Fiore F, Hinev A, Ghenev PI, Hristova MG, Panayotov $\mathrm{P}$, et al. From antitubulins to trackins. Biomed Rev 2016; 27: 59-67.

14a. Robertson S, Martinez GJ, Payet CA, Barraclough JY, Celermajer DS, Bursill C, et al. Colchicine therapy in acute coronary syndrome patients acts on caspase- 1 to suppress NLRP3 inflammasome monocyte activation. Clin Sci (Lond) 2016; 130:1237-1246. DOI: 10.1042/ CS20160090.

14b. Ridker PM, Howard CP, Walter V, Everett B, Libby P, Hensen J, et al; Group CPI. Effects of interleukin-1beta inhibition with canakinumab on hemoglobin A1c, lipids, C-reactive protein, interleukin-6, and fibrinogen: a phase IIb randomized, placebo-controlled trial. Circulation 2012;126: 2739-2748.

14c. Ghenev PI, Aloe L, Panayotov P, Fiore M, Zhelyaz- 
kova-Savova M, Chaldakov GN. Crystal deposition diseases (crystalopathies): their relevance to colchicine therapy. (Manuscript in preparation).

15. Chaldakov GN, Nabika T, Nara Y, Yamori Y. Cyclic AMP- and cytochalasin B-induced arborization in cultured aortic smooth muscle cells: its cytopharmacological characterization. Cell Tissue Res 1989;255:435-442. PMID: 2538239.

16. Vaidya K, Arnott C, Martínez GJ, Ng B, McCormack $\mathrm{S}$, Sullivan DR, et al. Colchicine therapy and plaque stabilization in patients with acute coronary syndrome: A CT Coronary Angiography Study. JACC Cardiovasc Imaging 2017. DOI: 10.1016/j.jcmg.2017.08.013.

17. Lennerz C, Barman M, Tantawy M, Sopher M, Whittaker P. Colchicine for prevention of post-cardiac procedure atrial fibrillation: Systematic review and metaanalysis. Int $J$ Cardiol 2017;249:127-137. DOI: 10.1016/j.ijcard.2017.08.039.

18. Salih M, Smer A, Charnigo R, Ayan M, Darrat YH, Traina M, et al. Colchicine for prevention of postcardiac pro-cedure atrial fibrillation: Meta-analysis of randomized controlled trials. Int J Cardiol 2017; 243:258-262. DOI: 10.1016/j.ijcard.2017.04.022.

19. Hemkens LG, Ewald H, Gloy VL, Arpagaus A, Olu KK, Nidorf $\mathrm{M}$, et al. Cardiovascular effects and safety of long-term colchicine treatment: Cochrane review and meta-analysis. Heart 2016;102:590-596. DOI: 10.1136/ heartjnl-2015-308542.

20. Lee JZ, Singh N, Howe CL, Low S-W, Huang JJ, Ortega $\mathrm{G}$, et al.Colchicine for prevention of post-operative atrial fibrillation. J Am Coll Cardiol Clin Electrophysiol 2016; 2:78-85. DOI:10.1016/j.jacep.2015.09.016.

21. Campbell KB, Cicci TA, Vora AK, Burgess LD. Beyond gout: Colchicine use in the cardiovascular patient. Hosp Pharm 2015;50:859-867 DOI: 10.1310/hpj5010-859.

22. Nidorf SM, Eikelboom JW, Budgeon CA, Thompson PL. Low-dose colchicine for secondary prevention of cardiovascular disease. J Am Coll Cardiol 2013;61:404410. DOI: 10.1016/j.jacc.2012.10.027.

23. Vogel RA, Forrester JS. Cooling off hot hearts: A specific therapy for vulnerable plaque? $\mathrm{J} \mathrm{Am}$ Coll Cardiol 2013; 61:411-412. DOI: 10.1016/j.jacc.2012.10.026.
24. Alsarah A, Alsara O, Laird-Fick HS. Cardiac manifestations of Familial Mediterranean fever. Avicenna J Med 2017; 7: 158-163. DOI: 10.4103/ajm.AJM_78_17.

25. Antonopoulos AS, Papanikolaou E, Vogiatzi G, Oikonomou E, Tousoulis D. Anti-inflammatory agents in peripheral arterial disease. Curr Opin Pharmacol 2017;39:1-8. DOI: 10.1016/j.coph.2017.11.001.

26. Akodad M, Fauconnier J, Sicard P, Huet F, Blandel $\mathrm{F}$, Bourret A, et al. Interest of colchicine in the treatment of acute myocardial infarct responsible for heart failure in a mouse model. Int J Cardiol 2017; 240:347-353. DOI 10.1016/j.ijcard.2017.03.126.

27. Cheng G, Kasiganesan H, Baicu CF, Wallenborn JG, Kuppuswamy D, Cooper G 4th. Cytoskeletal role in protection of the failing heart by $\beta$-adrenergic blockade. Am J Physiol Heart Circ Physiol 2012;302:H675-H687. DOI: 10.1152/ajpheart.00867.2011.

28. Cheng G, Takahashi M, Shunmugavel A, Wallenborn JG, DePaoli-Roach AA, Gergs Y, et al. Basis for MAP4 dephosphorylation-related microtubule network densification in pressure overload cardiac hypertrophy. $J$ Biol Chem 2010; 285: 38125-38140. DOI:10.1074/jbc. M110.148650.

29. Dybkova N, Wagner S, Back J, Hund TJ, Mohler PJ, Sowa $\mathrm{T}$, et al. Tubulin polymerization disrupts cardiac $\beta$ adrenergic regulation of late $\mathrm{INa}$. Cardiovasc Res 2014;103:168-177. DOI: 10.1093/cvr/cvu120.

30. Chaldakov GN, Fiore M, Ghenev PI, Stankulov IS, Angellucci F, Pavlov PS, et al. Conceptual novelties in atherogenesis: Smooth muscle cells, adventitia, and adipose tissue. Biomed Rev 2000; 11: 63-67.

31. Ghenev PI, Kisheva AR, Chaldakov GN. Quo vadis, atherogenesis? Part 1. Smooth muscle cell secretion - how foe becomes friend in the fight against the vul-nerable atherosclerotic plaque. Biomed Rev 2017; 28: 117-121.

32. Chaldakov GN. In: Cell Biology Textbook. Medical University Press, Varna, Bulgaria. 2014 (in Bulgarian).

33. Sansbury BE, Spite M. Resolution of acute inflammation and the role of resolvins in immunity, thrombosis and vascular biology. Circ Res 2016; 119(1): 113-130. DOI: 10.1161/CIRCRESAHA.116.307308 